\title{
Meningkatkan Pemahaman Siswa Terhadap Operasi Penjumlahan Bilangan Pecahan Dengan Menggunakan Gambar Luas Daerah di Kelas IV SD Inpres Maccini Sombal Kota Makassar
}

\author{
Latri Aras ${ }^{1}$, Rahmawati Patta ${ }^{2}$, Bahar $^{3}$ \\ ${ }^{123}$ Program Studi PGSD Fakultas Ilmu Pendidikan Universitas Negeri Makassar \\ ${ }^{1}$ unmlatri2014@gmail.com \\ ${ }^{2}$ rahma.patta@yahoo.com \\ 33baharmat@yahoo.co.id
}

\section{ABSTRACT}

This research is a class action that includes planning, implementation, obervation, and reflection. Data in the research are data activity and students learning outcomes in the addition fractions. Data obtained by obervation, testing, field notes which aims to improve understanding of the add fractions by using an image area of fourth grade students SD Inpres Maccini Sombala Makassar. The benefits of this research are (1) to provide direct experience of the ability of comprehensive applications of the use of the image area in an effort to improve the capability of addition fractions, (2) as an improvement of teaching on the subject of the addition fractions. The results of this research are the first cycle that (1) presenttasion on stage percentage in wide image the area is not maximized, (2) students has diffuculty in summing fractions, and (3) working group has not been maximized. While in the second cycle has that significant improvement; (1) presentation on stage percentage in wide image the area has a maximum running in accordance with the plan, (2) the students has mastered fractions addition operation using the image of area, and (3) students can work in groups optimally operate the sum fractions by using a wide image area. The improvement can be seen in the fisrt cycle qualifications less (K), the second cycle qualification of good (B). The conclusions of this research is to use the image in the area of learning fractions can enhance students undertanding fourth grade SD Inpress Maccini Sombala Makassar.

Keyword: fractions, additions, wide of image the area

PENDAHULUAN
Matematika sebagai ilmu dasar sangat
memegang peranan penting dalam
pengembangan ilmu pengetahuan dan
teknologi, misalnya dalam pengembangan ilmu
ekonomi, biologi, kimia dan fisika
memerlukan matematika sehingga matematika
seharusnya dikuasai sedini mungkin oleh para
siswa baik aspek terapannya maupun aspek
penalarannya. Mengkonkretkan materi yang
abstrak akan memberikan kesempatan bagi
siswa untuk dapat mengembangkan
kemampuannya dalam menciptakan suasana
belajar yang kondusif, dan guru dapat
menerapkan pembelajaran matematika yang
sesuai dengan materi yang disajikan,
sebagaimana Teori Piaget (Muhsetyo, 2005)
yang menyatakan bahwa anak-anak usia
sekolah dasar 7-12 tahun masih berada dalam
tahap operasional konkret.
Untuk menciptakan pemahaman siswa,
pengkonkretan obyek-obyek yang dipelajari
akan membentuk pemahaman yang bermakna

pada diri dan dapat meningkatkan siswa. Matematika sebagai ilmu dan struktur dalam hubungannya dengan simbol-simbol yang diperlukan. Simbol-simbol itu sangat penting untuk membantu memanipulasi aturan-aturan operasi yang ditetapkan, dan simbol-simbol juga dapat menjamin adanya komunikasi dan mampu memberikan keterangan untuk membentuk suatu konsep baru (Hudoyo, 1990). Selama ini pembelajaran matematika masih mengikuti kebiasaan dengan urutan materimateri pelajaran seperti: (1) diajarkan teori/defInisi/teorema, (2) diberikan contohcontoh, (3) diberikan latihan-latihan soal (Ingana, 2003).

Telah dijelaskan dalam Kurikulum Tingkat Satuan Pendidikan (KTSP) bahwa salah satu materi matematika yang sulit dipahami siswa adalah operasi penjumlahan pecahan, dalam hal ini jika penguasaan pokok bahasan pecahan rendah, maka kemampuan matematika siswa pada tahap berikutnya akan semakin rendah. Mengingat bahwa 
kemampuan siswa melakukan operasi pecahan sangat dibutuhkan dalam pengembangan pengetahuan matematika selanjutnya, penanaman konsep harus diberikan sedini mungkin.Untuk dapat memecahkan masalahmasalah yang terjadi di sekitarnya, misalnya penyelesaian soal-soal cerita, luas, dan volume bangun-bangun geometri. Semuanya membutuhkan pengetahauan operasi pecahan, maka sangatlah penting penggunaan bendabenda konkret agar mudah dipahami siswa, jika bentuk abstrak dibuatkan konkretnya yang tepat dalam mengajarkannya (Hudoyo, 1996).

Berdasarkan hasil observasi di SD Inpres Maccini Sombala diperoleh informasi dari guru bahwa masih banyak materi matematika di sekolah dasar belum dikuasai siswa salah satunya adalah bilangan pecahan dan operasinya. Guru telah mengajar dengan baik namun siswa belum juga menguasai sepenuhnya, disebabkan karena guru mengajar tidak menggunakan benda konkret, guru beranggapan bahwa menggunakan alat peraga hanya memakan waktu yanga lama sehingga waktu mengajar yang direncanakan tidak terlaksanakan dengan efisien. Keadaan seperti ini membuat siswa tidak maksimal menyerap pelajaran yang disajikan oleh guru, sehinggga siswa tidak memahami pembelajaran khususnya operasi penjumlahan bilangan pecahan. Guru hanya memberikan penjelasanpenjelasan materi yang berupa penjelasan dan pemberian soal-soal latihan, tanpa mengkonkretkan bilangan-bilangan pecahan yang diajarkan.

Pengajaran dengan menggunakan alat peraga akan memberikan hasil belajar siswa lebih cepat, lebih meningkat, dan lebih menarik. Arsyad (2004) mengatakan bahwa belajar melalui stimulus gambar dan stimulus visual membuahkan hasil belajar yang lebih baik seperti mengingat, mengenali, mengingat kembali serta menghubungkan antara fakta dan konsep. Perbandingan perolehan hasil belajar melalui indera pandang dan indera dengar sangat menonjol perbedaannya. Kurang lebih $90 \%$ hasil belajar seseorang diperoleh melalui indera pandang dan hanya sekotar 5\% diperoleh melalui indera dengar, kemudian 5 $\%$ lagi dengan indera lainnya (Arsyad, 2004). Dari penjelasan di atas tampak bahwa pembelajaran dengan menggunakan alat peraga (luas daerah bangun persegi, persegi panjang, segitiga, dan lingkaran) menguatkan pemahaman siswa kelas IV SD Inpres Maccini Sombala terhadap permasalahan operasi penjumlahan bilangan pecahan dan dapat meningkatkan kreativitas siswa dalam menyelesaikan suatu permasalahan yang ada dalam operasi penjumlahan pecahan.

Berdasarkan pada uraian pada latar belakang di atas, penulis melakukan suatu penelitian tindakan dengan judul "Meningkatkan Pemahaman Siswa Terhadap Operasi Penjumlahan Bilangan Pecahan dengan menggunakan Gambar luas daerah di SD Inpres Maccini Sombala Kota Makassar".

\section{METODE PENELITIAN}

a. Jenis Penelitian

Penelitian ini adalah Penelitian Tindakan Kelas (PTK) karakteristik yang khas dari penelitian ini yakni tindakan-tindakan (aksi) yang berulang-ulang untuk memperbaiki proses belajar mengajar di kelas. Model tindakan yang dilakukan dalam penelitian ini adalah model Kemmis dan Mc Taggart yang menyatakan bahwa proses penelitian tindakan merupakan sebuah siklus atau proses daur ulang yang terdiri dari empat aspek fundamental diawali dari aspek mengembangkan perencanaan kemudian melakukan tindakan sesuai dengan rencana, observasi/pengamatan terhadap tindakan, dan diakhiri dengan melakukan refleksi.

\section{b. Setting Penelitian}

Subyek penelitian adalah siswa SD Inpres Maccini Sombala yang aktif dan terdaftar pada semester genap tahun ajaran 2015/2016 dengan sasaran utama meningkatkan kemampuan siswa memahami konsep operasi penjumalah bilangan pecahan melalui penggunaan gambar luas daerah.

\section{c. Faktor yang di selidiki}

Untuk mejawab permasalahan di atas, ada beberapa factor yang akan diselidiki, yaitu :

1. Faktor Siswa, yaitu dengan melihat apakah tingkat kemampuan siswa pada pokok bahasan penjumlahan pecahan dalam kategori rendah, sedang atau tinggi.

2. Faktor guru yaitu dengan memperhatikan bagaimana persiapan materi dan kesesuaian pendekatan pembelajaran yang digunakan dalam pembelajaran penjumalahan pecahan.

3. Faktor sumber belajar yaitu dengan memperhatikan sumber belajar yang digunakan apakah sesuai dengan tujuan yang hendak dicapai, demikian pula latihan-latihan yang diberikan, apakah sudah berjenjang sesuai dengan tingkat kemampuan siswa serta dengan tujuan 
yang akan dicapai sesuai dengan tahapan penggunaan gambar luas daerah sebagai media pembelajaran.

\section{d. Teknik Pengumpulan data}

Untuk pengumpulan data dalam penelitian ini di lakukan dengan tes, wawancara, pengamatan, dan catatan lapangan.

\section{e. Analisis Data}

Analisis data dalam penelitian ini dilakukan selama dan sesudah pengumpulan data. Analisis data dilakukan dengan membandingkan hasil pengamatan, Wawancara, Catatan lapangan dengan indikator-indikator pada tahap refleksi dari data penelitian. Data yang terkumpul dianalisis dengan menggunakan analisis kualitatif yang yang terdiri dari tiga tahap kegiatan yang dilakukan secara berurutan, yaitu: mereduksi data, (2) menyajikan data, (3) menarik kesimpulan, (4) vertifikasi data.

\section{f. Pengecekan Keabsahan Data}

Untuk mengecek keabsahan data digunakan teknik triangulasi dan teknik diskusi dengan teman sejawat. Moleong (1998) mengemukan triangulasi adalah teknik pengecekan keabsahan data yang melibatkan sesuatu yang lain di luar data itu untuk keperluan pengecekan atau sebagai pembanding terhadap data itu.

Ada dua teknik triangulasi yang dilakukan dalam penelitian ini, triangulasi dengan metode dan triangulasi dengan sumber. Triangulasi dengan metode dilakukan dengan cara membandingkan dan mengecek balik sesuatu informasi yang diproleh melalui observasi, wawancara, catatan lapangan, dan tes akhir tindakan. Triangulasi dengan sumber dilakukan dengan cara membandingkan data hasil observasi teman sejawat dan observasi peneliti dengan hasil wawancara.

\section{HASIL \& PEMBAHASAN}

Berdasarkan hasil tes awal diperoleh informasi bahwa subyek penelitian tidak dapat menjawab soal $3,4,5$ yaitu masih melakukan kesalahan pada pola menentukan lambang bilangan yang diarsir. Skor tes awal Subyek penelitian hanya sebagian menjawab soal no 1 dan 2 dengan benar, untuk mengetahui alasan jawaban yang belum dipahami subyek penelitian, maka dilakukan wawancara. Berdasarkan tes awal dan wawancara, disimpulkan bahwa masih dirasa perlu meningkatkan pemahaman siswa operasi penjumlahan pecahan.

Rencana pembelajaran untuk setiap tindakan telah disusun secara kolaborasi antara peneliti dan guru kelas IV. Rencana pembelajaran memuat (1) sub pokok bahasan, kelas/semester, dan waktu, (2) indikator pembelajaran (3) materi pembelajaran (4) materi prasyarat, (5) alat/media dan sumber dan (6) kegiatan pembelajaran.

Dalam pelaksanaan tindakan pembelajaran, dengan menggunakan gambar sebagai media peneliti bertindak sebagai guru. Tahap-tahap pembelajaran setiap tindakan yaitu penanaman konsep pecahan, pecahan senilai, dan penjumlahan pecahan. Deskripsi pembelajaran untuk keaktifan belajar dengan menggunakan gambar sebagai media pada penjumlahan pecahan biasa penyebut tidak sama disajikan sebanyak dua kali tindakan pembelajaran.

Pembelajaran pada tindakan siklus 1 difokuskan pada penjumlahan pecahan biasa berpenyebut tidak sama dan masing-masing pembilangnya 1 dengan menggunakan daerah bagian dari suatu derah luasan. Pembelajaran dilaksanakan dengan menerapkan pembelajaran dengan menggunakan gambar luas daerah sebagai media. Untuk memperoleh data tentang pelaksanaan tindakan siklus1 dilakukan pengamatan, wawancara, tes, dan catatan lapangan. Hasil pengamatan, wawancara, tes dan catatan lapangan selama pelaksanaan tindakan dianalisis dan didiskusikan dengan pengamat sehingga diperoleh hal-hal sebagai berkut:

1. Penyajian pada tahap presentase untuk memperagakan penjumlahan pecahan biasa berpenyebut tidak sama dengan menggunakan daerah bagian dari suatu daerah luasan berjalan sebagaimaa yang telah direncanakan, namun untuk belajar dengan menggunakan gambar sebagai media disiapkan waktu yang cukup untuk kegiatan tersebut.

2. Siswa mengalami kesulitan dalam mengerjakan soal penjumlahan pecahan dengan alat peraga berupa karton yang berbentuk persegi panjang, segitiga, dan lingkaran. Kesulitan yang dialami siswa adalah belum memahami makna pecahan yang ada pada alat peraga yang diberikan.

3. Kerja kelompok siswa belum maksimal karena masih banyak siswa yang melakukan aktivitas lain pada saat diskusi kelompok. 
4. Pembelajaran secara kelompok masih didominasi oleh siswa yang berkemampuan tinggi sehingga keaktifan siswa yang lain masih kurang.

5. Sebagian besar siswa masih ragu-ragu dalam mengemukakan ide atau pendapat bila ditanya oleh guru terkait dengan pembelajaran.

6. Masih banyak ditemukan siswa yang raguragu untuk menanyakan hal-hal yang dianggap belum jelas baginya.

Berdasarkan analisis dan refleksi pada tindakan siklus 1 dan mengacu pada kriteria sukses yang ditetapkan maka pembelajaran pada tindakan siklus 1 belum berhasil, dimana berdasarkan hasil tes masih ditemukan siswa yang mencapai nilai kurang dari 6,5 .

Hasil analisis dan refleksi pada tindakan siklus 1, semua subyek penelitian secara umum sudah mencapai indikator pembelajaran namun yang diharapkan yaitu dapat menentukan langkah-langkah untuk menyelesaikan soal-soal penjumlahan pecahan biasa berpenyebut tidak sama yang masingmasing pembilangnya 1 dan yang salasatu penyebutnya merupakan kelipatan penyebut yang lain. bukan kelipatan salah satunya, dengan luas daerah bagian yang diarsir. Karena itu pembelajaran dilanjutkan dengan pembelajaran tindakan siklus II.

Pembelajaran tindakan siklus II difokuskan pada penjumlahan pecahan biasa dengan menggunakan luasan daerah yang diarsir. Pembelajaran pada tindakan siklus II ini juga menerapkan belajar klasikal dan untuk memperoleh data tentang pelaksanaan tindakan siklus II dilakukan pengamatan, wawancara, tes, dan catatan lapangan. Selama pelaksanan tindakan dianalisis dan didiskusikan dengan pengamat diperoleh hal-hal sebagai berikut:

1. Penyajian pada tahap presentasi untuk meragakan langkah-langkah menyelesaikan soal untuk penjumlahan pecahan biasa dengan menggunakan gambar luas daerah berlangsung sesuai rencana.

2. Siswa merasa senang mengerjakan soal penjumlahan pecahan dengan alat peraga berupa karton berbentuk persegi panjng, segitiga dan lingkaran yang disediakan

3. Siswa tidak mengalami kesulitan membagi bagian yang sama besar setelah diberi bimbingan seperlunyaoleh peneliti. Akhirnya siswa dapat mengerjakan sendiri

4. Siswa dapat menentukan langkah-langkah menyelesaikan soal untuk memperoleh hasil penjumlahan pecahan dengan menggunakan gambar luas daerah

5. Hasil tes tindakan siklus II menunjukan kemajuan, semua subyek penelitian memperoleh skor sesuai dengan yang diharapkan.

Berdasarkan hasil analisis dan refleksi dan mengacu pada kriteria sukses yang ditetapkan maka pembelajaran telah selesai. Dimana siswa telah memiliki pemahaman tentang penjumlahan pecahan dengan nilai rata-rata 7,5 .

Hasil penelitian terhadap aktifitas dan hasil belajar dengan menggunakan gambar luas daerah, melalui tiga tahapan yaitu, konsep pecahan, pecahan senilai, dan penjumlahan pecahan. Pada siklus pertama tindakan siklus I dan tindakan siklus II mengalami peningkatan yang signifikan.

Hasil tindakan siklus I pertama belum mencapai hasil yang diharapkan karena sebagian subyek belum memahami pecahan, yang terdiri dari menentukan KPK, pecahan senilai, dan penjumlahan pecahan. pada tahap pertama menggunakan gambar luas daerah dalam penjumlahan pecahan siswa belum dapat menentukan lambang bilangan pecahan daerah yang diarsir, Namun siswa aktif dalam pembelajaran dan menyadari pentingnya memahami operasi penjumlahan pecahan. Hal ini terbukti bahwa siswa sudah memahami penjumlahan pecahan yang luas, akan menghasilkan pengetahuan yang berarti dalam kehidupan sehari-hari.

Keberhasilan tindakan siklus II mencapai kualifikasi yang sangat baik, karena pada kegiatan yang terakhir dalam penjumlahan pecahan siswa mampu menjumlahkan pecahan dengan menggunakan gambar luas daerah dengan arsiran. Hal ini menunjukan bahwa siswa telah memahami makna model dan luas daerah arsiran pada pecahan, sejalan dengan penjelasan dan prediksi oleh Herawati (1994) bahwa dalam pembelajaran matematika utamanya pada jenjang sekolah dasar sangat diperlukan suatu teknik yang tepat agar konsep matematika yang diajarkan dapat dipahami dengan baik oleh siswa. Salah satu teknik yang digunakan adalah penggunaan gambar luas daerah sebagai media pembelajaran untuk menjelaskan suatu konsep khususnya penjumlahan bilangan pecahan, serta bertujuan untuk mengurangi tingkat abstraksi siswa.

Pada siklus pertama dari tindakan I sampai tindakan ke siklus II pada penelitian ini, siswa telah melakukan kegiatan operasi 
penjumlahan bilangan pecahan dengan kualifikasi sangat baik. Hal ini terlihat dari siswa telah memahami tahapan-tahapan ini yaitu tahap pemahaman dan penyempurnaan penjumlahan yang telah dihasilkan. Kegiatan penjumlahan pecahan adalah menjumlahkan bagian bagian dari suatu kesatuan yang utuh dibagi sama.

Keberhasilan tindakan pembelajaran dengan menggunakan gambar luas daerah pada penjumlahan pecahan disebabkan oleh kemampuan siswa dalam memahami konsep penjumlahan pecahan yaitu pemahaman dan kesempurnaan jawaban sesuai dengan langkahlangkah penjumlahan pecahan sejalan dengan teori pembelajaran yang dilaksanakan.

Selain keberhasilan karena adanya kemampuan siswa mengembangkan pemahamannya juga ditunjang oleh kemampuan dalam menerapkan konsep pecahan, sejalan dengan pendapat Hudoyo, (1990) bahwa matematika sebagai ilmu mengenai struktur dalam hubunganya dengan simbol-simbol sangat penting untuk membantu memanipulasi aturan-aturan dengan operasi yang ditetapkan. Simbol-simbol menjamin adanya komunikasi dan mampu memberikan keterangan untuk suatu konsep baru.

Jadi, penerapan gambar luas daerah sebagai media pembelajaran dalam penelitian ini dapat meningkatkan aktivitas dan tentunya hasil belajar matematika siswa khususnya pada pembelajaran operasi penjumlahan bilangan pecahan, sejalan dengan pendapat Soewito,(1992) mengemukakan bahwa "siswa yang melihat langsung pengertian konsepkonsep dari suatu materi pada benda-benda konkret yang sedang diperagakan dapat menimbulkan motivasi dan minat belajar siswa sekolah dasar".

\section{KESIMPULAN \& SARAN}

Penggunaan gambar luas daerah dalam pembelajaran penjumlahan pecahan dapat meningkatkan pemahaman siswa Kelas IV SD Inpres Maccini Sombala Kota Makassar. Hal ini dapat dilihat pada perkembangan setiap siklus. Pada siklus I belum menunjukkan hasil yang memuaskan setelah siklus II siswa telah memperoleh pemahaman tentang penjumlahan pecahan.

Proses pembelajaran dengan menggunakan gambar luas daerah dari aspek guru dan siswa dapat dicapai karena dari tindakan ketindakan refleksi dan perbaikan dengan melalui kolaborasi yang baik dengan pihak terkait dalam penelitian. Hasil belajar dengan menggunakan gambar luas daerah siswa Kelas IV SD Inpres Maccini Sombala telah mengalami peningkatan khususnya pada pembelajaran penjumlahan pecahan.

\section{DAFTAR PUSTAKA}

Arsyad, Azhar, 2004. Media Pembelajaran. Jakarta: PT Raja Grafindo Persada

Hartono, P. 2003. Tahap-Tahap Perkembangan Kognitif Siswa: Depdiknas Jakarta

Herawati Susi.1994. Memantapkan Penggunaan Model Bagian Suatu Daerah Untuk Mengajarkan Penjumlahan Pecahan: IKIP SURABAYA

Hudoyo, Herman. 1990. Mengajar Beajar Matematika Usaha Nasional : Surabaya

-------. 1996. Pengembangan Kurikulum Matematika dan Pelaksanaannya di Depan Kelas. Usaha Nasional: Suarabaya

Inganah S. 2003. Model Pembelajaran Segi Empat Dengan Pendekatan Realistik Pada Siswa Kelas II SLTP Negeri III Batu.Tesis Tidak Diterbitkan

Latri. 2003. Pembelajaran Volume Kubus dan Balok Secara Kontribusi Dengan Menggunakan Alat Peraga di Kelas V SDN 10 Watampone. Proposal Tesis Tidak Diterbitkan

Miles, M.B dan Huberman. Analisis Data Kualitatif. Terjemahan oleh Tjeptjep Rohidi 1992 Jakarta UI Press

Moleong, L.J 1994 Metodologi Penelitian Kualitatif. Remajarosdakarya. Bandung

Muhsetio G. 2005. Pembelajaran Matematika di $S D$ : Universitas Terbuka

Ramadhoni,R. 1996. Anlisis Kemampuan Menyelesaikan Kemampuan Operasi Pecahan dalam Soal Cerita Matematika. Skripsi. FPMIPA IKIP Ujung Pandang.

Roi Jokers. 1991. Mengajar dengan Sukses: Gresindo Jakarta

Rusiyan, Tabrani. 1989. Pendekatan Dalam Proses Belajar Mengajar : Remaja Karya Bandung

Susanto, 2007. Pengembangan KTSP Dengan Manajemen Visi. Jakarta

Soenarto Sunaryo. 2002. Interaksi Pembelajaran dan Pengelolaan Kelas. Depdiknas: Jakarta

Sukarman, Herry. 2002. Pengelolaan Proses Belajar Mengajar. Depdiknas. 
Tiro, M Arif 1994. Cara Mengajar Konsep Pecahan di Sekolah Dasar

"Transfprmasi" Vol. 1 1994. Ujung pandang.

Winkel, W.S. 1991. Psikologi Pengajaran.

Remaja Karya: Bandung

Wiriaatmadja R, 2005. Metode Penelitian

Tindakan Kelas. Remaja Rosda Karya:

Bandung 